\title{
Small bowel extracts in the inhibition of tumour growth
}

\author{
P. CHAN, K. C. CALMAN'1, AND T. A. CONNOR \\ From the Departments of Surgery and Oncology, Western Infirmary, Glasgow, and Chester Beatty Research \\ Institute, London
}

SUMMARY Results presented in this paper confirm earlier experiments which showed that microsomal extract of small bowel, preincubated with tumour cells, resulted in complete inhibition of tumour growth. However, experiments in vitro have shown that this effect is due to direct cytotoxicity of the extract and that (a) it is not specific for the small bowel; (b) it is not specific for tumour cells; and (c) the activity is predominantly in the mitochondrial fraction.

In 1951 Bennett, Connon, and Schoenberg reported that preincubation of tumour cells with an extract of small bowel composed of microsomes could prevent the growth of the Gardner lymphoma in mice. This effect, they stated, was specific for small bowel. The purpose of this paper was to repeat their experiments and, if confirmed, extend these findings and to examine the specificity of an extract of small bowel in inhibiting tumour growth.

\section{Methods}

PREPARATION OF EXTRACTS

For each experiment three CBA mice were killed and the small bowel, large bowel, stomach and liver were removed. The liver was rinsed with cold isotonic saline and the intestinal organs were opened and flushed clear of all intestinal content. The organs were then weighed and homogenized separately, after adding $4 \mathrm{ml}$ cold isotonic saline per gram, using a Teflon-glass homogenizer for one minute. After filtering through a double layer of gauze, the suspensions were centrifuged at $4000 \mathrm{~g}$ for 20 minutes. The pellet, used in subsequent experiments, is called fraction $\mathrm{I}$. The supernatant was centrifuged at $100000 \mathrm{~g}$ for one hour and the pellet (fraction II) and supernatant (fraction III) were assayed for activity.

\section{CONTROL CELL POPULATIONS}

The spleen was removed from a CBA mouse and gently sieved through a wire mesh sieve. This gave a single cell suspension with a viability, as assessed by trypan blue, over $95 \%$.

${ }^{1}$ Reprint requests to Professor K. C. Calman, Department of Oncology, Western Infirmary, Glasgow G11 6NT.

Received for publication 26 September 1974.
TUMOUR CELLS

The Gardner lymphoma (Gardner, Dougherty, and Williams, 1944) was maintained by serial intraperitoneal passage in CBA mice. For all tumour experiments $5 \times 10^{6}$ cells $/ \mathrm{ml}$ were inoculated intraperitoneally. In-vitro experiments were performed using cell suspensions of tumour cells after washing the cells with TC199. The TLX5 lymphoma (Connors and Jones, 1970) was also maintained and used as above.

\section{Experiments and Results}

THE EFFECT OF MICROSOMAL PREPARATION ON TUMOUR CELL GROWTH (FRACTION II) To $1 \mathrm{ml}$ of tumour cells $\left(5 \times 10^{6}\right.$ cells $\left./ \mathrm{ml}\right), 1 \mathrm{ml}$ of the microsomal fraction of either small bowel, liver, or a saline control was added and incubated at $37^{\circ} \mathrm{C}$ for two hours. From this mixture $0.1 \mathrm{ml}$ was injected intraperitoneally into three groups of $10 \mathrm{CBA}$ mice and the subsequent progress noted. The experiments were performed with both tumour systems.

The results are shown in tables I and II and confirm that preincubation of either the Gardner tumour

\begin{tabular}{llll}
\hline Extract & $\begin{array}{l}\text { No. of } \\
\text { Animals }\end{array}$ & $\begin{array}{l}\text { Mean Survival } \\
\text { Time (days) }\end{array}$ & $\begin{array}{l}\text { No. of } \\
\text { Survivors }\end{array}$ \\
\hline Liver & 10 & 10 & $0 / 10$ \\
Saline & 10 & 21 & $0 / 10$ \\
Small bowel & 10 & 1 & $10 / 10$ \\
\hline
\end{tabular}

Table I Effect of preincubation of microsomal extracts on the growth of Gardner tumour cells in vivo injected into $C B A$ mice

${ }^{1}$ All animals alive and free from tumour at three months. 


\begin{tabular}{llll}
\hline Extract & $\begin{array}{l}\text { No. of } \\
\text { Animals }\end{array}$ & $\begin{array}{l}\text { Mean Survival } \\
\text { Time (days) }\end{array}$ & $\begin{array}{l}\text { No. of } \\
\text { Survivors }\end{array}$ \\
\hline Liver & 10 & 10 & $0 / 10$ \\
Saline & 10 & 9 & $0 / 10$ \\
Small bowel & 10 & 1 & $10 / 10$
\end{tabular}

Table II Effect of preincubation of microsomal extracts on the growth of TLX5 tumour cells in vivo injected into CBA mice

${ }^{1}$ All animals alive and free from tumour at three months.

or the TLX5 with small bowel microsomes, but not liver microsomes or saline, protects against tumour growth.

IN-VITRO STUDIES ON THE EFFECT OF LIVER AND SMALL BOWEL MICROSOMES ON CELL VIABILITY

Cell suspensions of Gardner lymphoma, TLX5 lymphoma, and normal spleen were separately incubated with liver or small bowel microsomes as described above. At intervals, aliquots were taken and the viability of the cells was assessed by trypan blue exclusion. At the outset of all experiments cell viability was greater than $95 \%$.

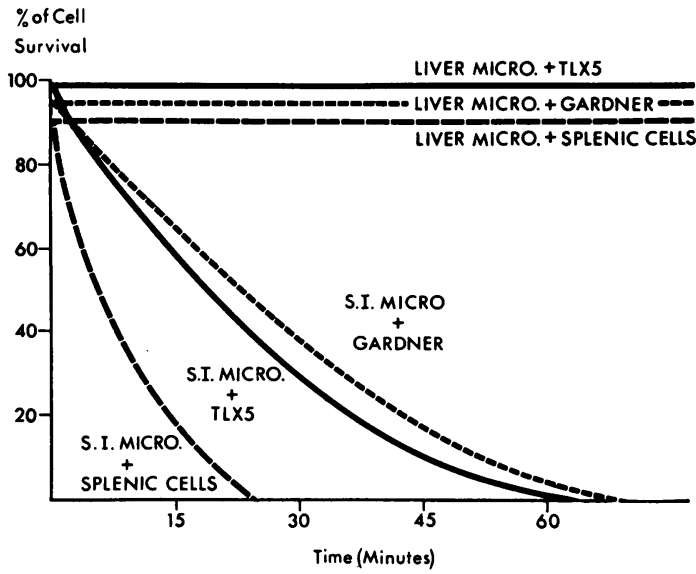

Fig 1 Effect of small intestine and liver microsomes on cell viability in vitro

The results are shown in fig 1 and are the mean of three separate experiments. They indicate that cell death occurs rapidly with both normal and tumour cells in the presence of small bowel microsomes but not with liver microsomes. It is also noted that the microsomes are more toxic to normal spleen cells than tumour cells.
IN-VITRO STUDIES ON CYTOTOXICITY USING VARIOUS SUBCELLULAR FRACTIONS OF SMALL BOWEL MUCOSA

The three fractions of small bowel extract prepared as described were incubated with $5 \times 10^{6}$ tumour cells. Viability was assessed by trypan blue exclusion.

The results are shown in fig 2 and are the mean of three separate experiments. It can be seen that the

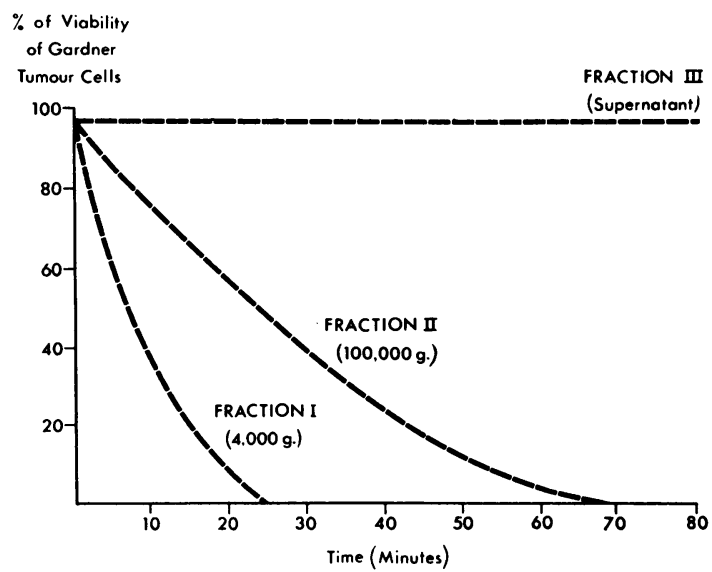

Fig 2 Effect of subcellular fractions on cell viability in vitro.

greatest activity is present in fraction I, the mitochondrial and brush border component. The microsomal component (fraction II) is also active but the supernatant (fraction III) shows no activity.

\section{IN-VITRO STUDIES ON THE SPECIFICITY OF INTESTINAL SITE ON TUMOUR CELL VIABILITY}

Subcellular fractions I, II, and III of stomach, small

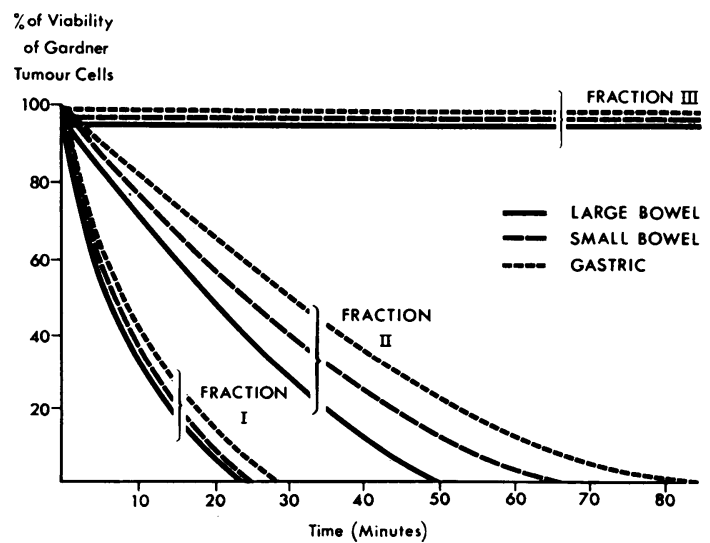

Fig 3 Effect of subcellular fractions from different sites on cell viability in vitro. 
intestine, and large intestine were incubated with Gardner lymphoma cells and the viability was assessed as before.

The results are shown in fig 3 and indicate that the activity is present in all three areas of the intestine. In the microsomal fraction there is some difference in activity, the small bowel fraction being the most active.

\section{Discussion}

The initial aim of this paper was to confirm the results reported in 1951 by Bennett et al and the first experiment performed in this publication is in agreement with the earlier study. However, in the subsequent studies in vitro it is clear that this activity is not specific to small bowel. In addition it is evident that the activity is not maximal in the microsomal fraction but is greatest in the mitochondrial and brush border pellet. Perhaps the most important feature is that the normal cells are killed more rapidly than tumour cells making the use of the extract less important in therapeutic terms.

The significance of the earlier results was related to the fact that tumours of the small bowel are rarer than tumours of other areas of the gastrointestinal tract and the suggestion was made that there may be something within the small bowel preventing tumour growth. Lowenfels (1973) has recently reviewed this subject and suggests that the rarity of small bowel tumours may be related to (1) the rapid transit of potentially carcinogenic substances in the small bowel; (2) the relative fluidity of the small bowel contents; (3) the relative sterility of the small bowel when compared with the large bowel. More recently Calman (1974) has suggested, and presented evidence in a small animal model to support the hypothesis, that the immunological status of the small bowel may be important.

It remains to establish the exact nature of the active component in gastrointestinal subcellular fractions. Certainly it contains a biological active substance(s) which will kill $100 \%$ of cells within 30 minutes. It is likely, however, that the activity is related to the enzymatic activity of gastrointestinal epithelium.

\section{References}

Bennett, L. R., Connon, F. E., and Schoenberg, M. D. (1951). Effect of ultracentrifugal fractions of small intestinal tissue upon transplanted lymphosarcoma. Proc. Soc. exp. Biol. (N.Y.), 78, 790-791.

Calman, K. C. (1974). Why are small bowel tumours rare? An experimental model. Gut, 15, 552-554.

Connors, T. A., and Jones, M. (1970). The effect of asparaginase on some animal-tumors. Rec. Results Cancer Res., 33, 180-187.

Gardner, W. U., Dougherty, T. F., and Williams, W. L. (1944). Lymphoid tumours in mice receiving steroid hormones. Cancer Res., 4, 73-87.

Lowenfels, A. B. (1973). Why are small-bowel tumours so rare? Lancet, 1, 24-25. 